\title{
A comparison of the labour market position of university education and higher vocational education in economics and business administration
}

Citation for published version (APA):

Arents, M., Heijke, J. A. M., \& Koeslag, M. (1996). A comparison of the labour market position of university education and higher vocational education in economics and business administration. Researchcentrum voor Onderwijs en Arbeidsmarkt, Faculteit der Economische Wetenschappen. ROA Research Memoranda No. 1E https://doi.org/10.26481/umaror.199601E

Document status and date:

Published: 01/01/1996

DOI:

10.26481/umaror.199601E

Document Version:

Publisher's PDF, also known as Version of record

Please check the document version of this publication:

- A submitted manuscript is the version of the article upon submission and before peer-review. There can be important differences between the submitted version and the official published version of record.

People interested in the research are advised to contact the author for the final version of the publication, or visit the DOI to the publisher's website.

- The final author version and the galley proof are versions of the publication after peer review.

- The final published version features the final layout of the paper including the volume, issue and page numbers.

Link to publication

\footnotetext{
General rights rights.

- You may freely distribute the URL identifying the publication in the public portal. please follow below link for the End User Agreement:

www.umlib.nl/taverne-license

Take down policy

If you believe that this document breaches copyright please contact us at:

repository@maastrichtuniversity.nl

providing details and we will investigate your claim.
}

Copyright and moral rights for the publications made accessible in the public portal are retained by the authors and/or other copyright owners and it is a condition of accessing publications that users recognise and abide by the legal requirements associated with these

- Users may download and print one copy of any publication from the public portal for the purpose of private study or research.

- You may not further distribute the material or use it for any profit-making activity or commercial gain

If the publication is distributed under the terms of Article $25 \mathrm{fa}$ of the Dutch Copyright Act, indicated by the "Taverne" license above, 


\title{
A Comparison of the Labour Market Position of University Education and Higher Vocational Education in Economics and Business Administration
}

\author{
Marike Arents*, Hans Heijke*, Mieke Koeslag**
}

ROA-RM-1996/1E

* Netherlands Economic Institute and Tinbergen Institute, Erasmus University Rotterdam.

** Research Centre for Education and the Labour Market, University of Limburg, Maastricht.

A previous version of this paper has been presented at the Seventh Annual Conference of the European Association of Labour Economists (EALE), Lyon, France, September 7-10, 1995.

Research Centre for Education and the Labour Market

Faculty of Economics and Business Administration

University of Limburg

Maastricht, January 1996 
Arents, Marike

A Comparison of the labour market position of university education and higher vocational education in economics and business administration / Marike Arents, Hans Heijke, Mieke Koeslag. - Maastricht: Research Centre for Education and the Labour Market, Faculty of Economics and Business Administration, University of Limburg. - (ROA-RM-1996/1E)

A previous version of this paper has been presented at the seventh annual conference of the European Association of Labour Economists (EALE), Lyon, France, September 7 - 10, 1995. - Met lit. opg.

ISBN 90-5321-166-7

Trefw.: economie-onderwijs en arbeidsmarkt 


\section{Contents}

Page

Abstract

i

1 Introduction 1

2 The labour market position of types of education 3

2.1 A typology 3

2.2 Theory $\quad 5$

2.3 Hypotheses $\quad 8$

3 The data 9

3.1 The HBO monitor and the RL scanner 9

3.2 The statistical definition of 'occupational domain' 11

4 Empirical analysis 12

4.1 Job opportunities $\quad 12$

4.2 Earnings 14

5 Conclusions 17

$\begin{array}{ll}\text { References } & 18\end{array}$

Appendix 1 The classification of occupational groups 21

Appendix 2 The mean characteristics of the respondents employed 23 



\section{Abstract}

In this paper the competition between two types of higher education in the Netherlands will be investigated; higher vocational education in economics and business administration on the one hand and university education in economics and business administration on the other hand. The aim is to explain differences in the labour market position by the level of the skills the schoolleavers have acquired.

Therefore, for each type of education an occupational domain is defined: a set of occupations in which the schoolleavers of the type of education concerned have a comparative advantage. For schoolleavers of each type of education, the job opportunities and the productivity inside and outside their occupational domain are investigated. 



\section{Introduction}

As in other European countries, the rate of participation in higher education has increased sharply in the Netherlands (OECD, 1993). In 1968, just $13 \%$ of school-leavers went on to higher education. This percentage increased to $21 \%$ in 1978 and $29 \%$ in 1990 (CBS, 1993). In addition to increased prosperity, which has made it possible to keep children at school longer and send them to higher, and thus more expensive, forms of education, the increased participation in higher education can be explained by the general notion in society that the higher the educational attainment, the better the opportunities on the labour market will be. Until the early 1990s, the opportunities on the labour market for people with higher education were indeed much better than for other school-leavers. Later, the opportunities for people with higher education worsened. The percentage of the labour force with higher education who were unemployed has increased markedly. Table 1.1 shows that, over a period of eighteen years, the unemployment rates for graduates from the two types of tertiary education in the Netherlands (i.e., higher vocational education and university education) has increased more than the average, although the rates are still on a relatively low level.

Table 1.1

Unemployment in the Netherlands, as a percentage of the labour force, by type of education

\begin{tabular}{lcccc}
\hline Type of education & 1975 & 1991 & 1992 & 1993 \\
\hline Higher vocational education & 1.9 & 4.8 & 4.9 & 5.1 \\
University education & 1.4 & 4.2 & 5.4 & 6.1 \\
All types of education & 4.1 & 6.5 & 6.5 & 7.5
\end{tabular}

Source: CBS (1994a, 1980)

As a result of the greater participation in higher education, and the growth of unemployment among the labour force with higher education, relatively more graduates may be inclined to accept jobs for which the requirements are different from their own acquired qualifications, such as jobs at a lower level or in a field other than the one in which they trained. Consequently, the rate of return on investments in higher education may be relatively low. In 1989, the social rate of return on investments in higher vocational education and university education in the Netherlands was $2.2 \%$ and $5.7 \%$ respectively (OSA, 1994). These rates are low in comparison with the general rate of return on capital.

Another consequence is a stronger competition between the two types of higher education, although their objectives and their educational level are said to be different. The following quotation from the Dutch Ministry of Education and Science (Ministerie $O$ \& W, 1985:21) may clarify this difference. "In addition to university education, higher vocational education ought to be constituted as a fully part of the system of higher education in the Netherlands. Higher vocational education ought to be focused on 
occupational training, whereas university education ought to be focused on more abstract training which is normally not connected with specific occupations ... The differences between these types of education are certainly not primarily caused by differences in the level, but especially caused by differences in educational objective." ${ }^{11}$ Higher vocational education is intended to prepare students for specific occupations, while in university education the emphasis is not primarily on the preparation for certain occupations but more on the development of a scientific attitude.

Another difference between higher vocational education and university education concerns the level of the required preliminary education. For higher vocational education, a certificate from senior general secondary education, intermediate vocational education or university preparatory education is required. University training requires a certificate in university preparatory education or a qualification from higher vocational education. So graduates from higher vocational education can move up to university education. For example, a graduate from higher vocational education in economics and business administration, whose preliminary education was senior general secondary education, can move up to university education in economics and business administration and is exempted from about one year of study.

This paper focuses on the competition between the two above mentioned specific types of higher education which are potential substitutes: higher vocational education, and university education, in the field of 'economics and business administration'. The aim of this paper is to provide an explanation of the relative labour market position of these types of higher education. The Ministry of Education and Science emphasises that the differences between both types of higher education are primarily caused by differences in their educational objectives and not by differences in their level (Min. O \& W, 1985:21). However, two remarks can be made with regard to this opinion. In the first place, there is a difference in the level of the required preliminary education. Secondly, many graduates from higher vocational education are inclined to move up to university education. In this paper, therefore, special attention is given to the specific role, which the level of the qualifications acquired in both types of higher education, plays in the competitive labour market position of their graduates.

The structure of the paper is as follows. Section 2 describes the two types of education in economics and business administration within the framework of a typology of the level of cognitive skills which can be acquired by education. Furthermore, the labour market position of the two types of education will be described from several theoretical points of

1. "Het HBO zou naast het WO een volwaardig onderdeel van het hoger onderwijssysteem moeten gaan vormen, waarbij het HBO zich zou richten op de directe beroepsgerichte opleidingen en het WO op de meer abstracte, in de regel niet aan specifieke beroepen verbonden opleidingen ... Het verschil in het HBO zou zeker niet in de eerste plaats gelegen zijn in een verschil in niveau maar in een verschil in opleidingsdoel". (Min. O \& W, 1985:21) 
view: the human capital theory, the theory of the labour queue (the 'job competition model') and the theory of matching will be discussed. With the help of this discussion, the determinants of the labour market position of the types of education can be deduced, and the occupational domain of the two types of higher education can be characterized. The section concludes with a number of hypotheses concerning the relative labour market position of the two types of higher education in economics, both within and outside their specific occupational domains. Section 3 describes the data set, and defines the concept of an occupational domain. The results of the analyses will be given in section 4 . The paper will be rounded off with some concluding remarks in section 5 .

\section{The labour market position of types of education}

\subsection{A typology}

Types of education can have a position on the labour market because of their role in the search and selection processes on the labour market. Employers use the personal characteristics of applicants, such as their educational attainments, in selecting between candidates for a job because educational attainments give employers information about the productive capacities of graduates. Generally, for employers, educational attainment is an inexpensive estimator of the productivity of potential workers. The position of types of education on the labour market is also important for students, in orienting themselves to the possibilities open to them on the labour market. Along with factors such as their ability to succeed in a particular type of study and their preferences with respect to the content of the course, they will be interested in choosing a type of education which has a good position on the labour market, and their options in searching for jobs after graduation will be largely determined by the occupational domain of the study.

On the labour market, there seem to be no great differences between higher vocational education and university education in economics. The unemployment figures for both studies are below the average level (see table 1.1), and student interest in both studies is growing. Forecasts of graduate numbers indicate that the percentage of all graduates from higher vocational education who qualify in economics will increase from $2.8 \%$ in $1991 / 1992$ to $4.8 \%$ in $1999 / 2000$. For university education, the percentage of graduates qualifying in economics is also predicted to increase, although less strongly, from $1.2 \%$ in $1991 / 1992$ to $1.5 \% 1999 / 2000$ (Min. O \& W, 1994).

However, it was noted in section 1 that the two types of education have different educational objectives. These differences have their origins in the level of the cognitive 
skills which are taught. ${ }^{2}$ This will be explained further. Bloom et al. (1956) have developed a taxonomy of cognitive skills which contains a ranking of categories of qualifications by levels (see table 2.1). The lowest category contains qualifications which can be acquired most easily. The higher ranked qualifications can only be acquired after lower ranked qualifications have been obtained. The ability to remember and understand learned material is a lower level of cognitive skill than the ability to put learned material together to make and evaluate a new entity.

Table 2.1

Summary of the taxonomy of cognitive skills by Bloom et al.

\section{Knowledge}

Defined as the remembering of previously learned material. Knowledge is seen as the lowest level of learning. For example, 'knowing methods and procedures'.

\section{Comprehension}

Comprehension is defined as the ability to grasp the meaning of material. It goes one step beyond the remembering of material, and it represents the lowest level of understanding. For example, 'interpreting charts and graphs'.

\section{Application}

Application means that the learned material can be used in new and concrete situations. This type of learning requires a higher level of understanding than comprehension. For example, 'applying laws and theories to practical situations'.

\section{Analysis}

This is the ability to break down material into parts, so that the organisational structure may be understood. This is a higher level of cognitive skill than comprehension and application because it requires an understanding of both the content and the structural forms of the material. For example, 'distinguishing between main points and side issues'.

\section{Synthesis}

This refers to the ability to put parts together to form a new whole. Here the emphasis is on the formulation of new patterns and new structures. For example, 'writing a research plan'.

\section{Evaluation}

Evaluation is concerned with the ability to judge the value of the material which is being learned. This type of learning is the highest in this hierarchy, because it contains elements of all the other categories of learning, in addition to the ability to judge learned material. For example, 'judging the value of work by use of internal criteria'.

Source: Bloom et al., 1956.

2. Types of higher education can also be differentiated by teaching other skills, such as social skills (Ramaekers \& Heijke 1994, Frederix, 1988). There may be differences between higher vocational education and university education in economics with regard to social skills. From our point of view differences in social skills will be noticeable mainly in the working context, so we have treated them as job-specific skills. 
On the lower level - the levels of knowledge and comprehension - the skills are not transferable to other contexts. For example, knowledge about specific rules, without application abilities, is only useful in the context for which the rules are designed. These type of cognitive skills can therefore be termed context-specific.

Cognitive skills on a higher level - the skills of application, analysis, synthesis and evaluation - are transferable to a variety of contexts. For example, the ability which is here termed 'application' is defined as the ability to transfer concepts and principles to new situations. The abilities of analyzing, synthesising and evaluating are utilisable in a variety of situations because these skills are more abstract. These non-context specific skills can be linked with learning ability, if learning ability is understood as adaptability.

With the help of this ranking of cognitive skills, and knowing the educational objectives of higher education in the Netherlands, higher vocational education and university education in economics and business administration in the Netherlands can be characterized. Higher vocational education in economics teaches high level cognitive skills. For example, graduates from higher vocational education have the ability to evaluate the material they learn. Because higher vocational education is intended to be focused on occupational training, graduates are not trained specifically in the transferability of these skills to occupations outside the specific domain. It is the fact that this type of education emphasises the application of skills in the context of a specific and restricted occupational domain which makes it vocational training. University education in economics also teaches high level cognitive skills, but because university education is not connected with occupational training in particular, but rather with the broader concept of a scientific discipline, the graduates of university education should receive better training in terms of learning abilities. They should be more able to analyse and develop theoretical concepts on an abstract level. So, using this taxonomy, the qualifications acquired by graduates of university education are of a higher level and are less occupation-specific. However the differences are clearly only a question of degree.

\subsection{Theory}

Three theories, which might be used to describe the impact of these differences between the two types of higher education in economics on the labour market position of their graduates, will be considered. These theories are: the human capital theory, the job competition model and matching models. All of these theories emphasise the possible relation between educational attainment and job opportunities and earnings in the labour market.

\section{Human capital theory}

The human capital theory (Schultz, 1961; Becker, 1962) explains differences in the 
productivity and earnings on the labour market. Human capital is defined as those personal abilities which determine people's productivity. Generally, investments in educational attainment are the most important source of human capital. Therefore differences in educational attainment between individuals result in differences in their productivity. The more educational attainment someone has, the more productive he or she would, as a general rule, be in a job.

The human capital theory assumes that there is wage competition in the labour market, so that wages are related to individual productivities in jobs. The more productive an individual is in a job, the higher his or her earnings will be. Since individuals' productivities are determined by their investment in human capital, wages are reflections of the benefits of human capital. The existence of wage competition means also that wages are an indication of the relative scarcity of human capital. If a specific type of human capital is relatively scarce on the labour market, employers will pay relatively more for it than if it was abundant.

\section{The job competition model}

According to the human capital theory, the individuals' productivities in particular jobs depends on personal abilities mainly. Thurow $(1975,1979)$ has developed a job competition model in which it is assumed that there is job competition, with other words: it is assumed that productivity and wages depend on the characteristics of the job, rather than on the abilities of the person who fulfills the job. Furthermore, it is assumed that differences in wages paid out in jobs can be determined institutionally.

The job competition model supposes that new entrants come on to the labour market with a variety of background characteristics. They may, for example, differ in sex, level of educational attainment, working experience, age or race. These background characteristics play an important role in the labour market, because they determine the costs of training an employee to obtain the level of productivity required in a particular job. Workers are ranked in a labour queue, with those whose background characteristics cause the highest training costs ranked at the bottom, and those whose characteristics indicate the lowest training costs at the top. Since the level of educational attainment gives an indication of the learning ability of an individual, it is an important indicator of trainability and therefore of the individual's relative position in a labour queue.

The job competition model shows that the learning ability attributed to a type of education is an important explanation of the position of types of education on the labour market. Furthermore, the model has shown that factors on the demand side of the labour market, such as job characteristics, are also important determinants of the position of types of education on the labour market. 
The theory of job matching in relation to educational attainment is largely developed in mathematical models (Jovanovic, 1979). In job matching models, interactions between personal abilities and job characteristics are emphasised as determinants of an individual's productivity in a job (Hartog \& Visser, 1987). Thus productivity in a job is not dependent only on personal abilities, but it is also not completely determined by the characteristics of the job: rather it is a result of the combination of job characteristics and personal abilities. Given their individual abilities, some people are more suited to certain jobs and less suited to other jobs, whereas for other people the situation may be more or less reversed. These differences have consequences for their job opportunities. The following example, based on an analogous example described by Samuelson \& Nordhaus (1985) may clarify this. Suppose there are two jobs vacant in a free market situation, one involving typing activities and the other teaching activities. For these jobs, two persons are available: a secretary and a professor. Suppose productivity can be valued on a scale from zero to ten, and that candidates' wage expectations reflect their productivity in the job for which they are best suited. The secretary's productivity is assumed to be six for typing activities and four for teaching activities, while the professor's productivity is assumed to be seven for typing activities and eight for teaching activities. Although the professor is more productive in typing activities than the secretary, the most preferred match is obtained if the secretary gets the job with typing activities and the professor gets the teaching job. Assuming the market mechanism functions well, the allocation process will ensure that both are employed according to their best capacities, and the secretary has a comparative advantage in typing activities, while the professor has a comparative advantage in teaching activities. Because of their comparative advantage in certain kinds of occupations, graduates of some types of education have better job opportunities in those occupations than others (Hartog, 1992).

Matching models implicitly assume that individual suppliers of labour differ in the extent to which the qualifications they have acquired during their education are matched to the requirements of specific jobs. Because of these differences some people are better qualified for certain jobs and are therefore more productive in these jobs than other people. It is also assumed that earnings are based on a person's productivity in a job. People's earnings will be highest in jobs for which they have a comparative advantage.

\section{Determinants of the labour market position}

With the help of the theories mentioned above, we can deduce the determinants of the labour market position of types of education, i.e., which of the diverse characteristics of various types of education affect the labour market position of their graduates. Three principal determinants are distinguished here:

- the qualification level; 
- the learning ability or the occupational specificity of the qualifications;

- the comparative advantage.

The qualification level which graduates acquire is emphasised especially by the human capital theory, and learning ability is emphasised in the job competition model, while matching models show that some types of education have a comparative advantage over other types of education in certain kind of occupations. The latter implies that each type of education has his own occupational domain: the set of occupations in which that type of education has a comparative advantage. So the occupational domain of higher vocational education in economics contains occupations in which the graduates of this type of education have a comparative advantage in comparison with graduates of other types of education. The occupational domain of the graduates of university education in economics can be typified in the same way. Because of the differences in the acquired learning ability and the occupational specificity of the acquired qualifications, it is plausible to suppose that each type of education has its own occupational domain, but that the occupational domain of university education in economics will be wider.

Because of fluctuations in the relative scarcity of the supply of the two groups graduates, labour market imperfections and heterogeneity in the demand, in practice the occupational domains will contain graduates of both types of higher education in economics.

\subsection{Hypotheses}

It is plausible that higher vocational education and university education would have largely different occupational domains, because graduates from these types of education should differ in the degree of learning ability and the occupational specificity of the acquired qualifications. University graduates in economics have acquired a greater learning ability, but their qualifications are less strongly connected to specific occupations. Furthermore, section 2.2 has shown that these aspects are important determinants of the labour market position of types of education. So, it is to be expected that:

1. University graduates in economics and graduates of higher vocational education in economics have the best chance of finding a job in their own occupational domain (the own domain hypothesis).

2. University graduates in economics are more likely to find a job in the occupational domain of higher vocational education in economics, than graduates of higher vocational education in economics do in the occupational domain of university economists (the alternative domain hypothesis).

Section 2.2 has shown also that earnings can be considered as a reward for productivity. The human capital theory claims that the higher the investment in human capital is, the higher the productivity and earnings will be. According to the job competition model, 
earnings are dependent on the level of educational attainment, too, but for another reason. In this theory the higher the educational attainment, the higher the learning ability will be, and the better the possibilities of getting the best paid jobs in the labour market. The matching models, however, claim that productivity and earnings are especially determined by the relative quality of the match between qualifications acquired and required. So these theories can be used to emphasise the impact of the acquired qualification level, learning ability, the occupational specificity of the acquired qualifications and the quality of the match between qualifications required and acquired on the relative earnings of the graduates of both types of higher education in economics in the two occupational domains. This leads to the third hypothesis:

3. Because the match between the qualifications acquired and required is the best in the graduates' own occupational domain, they will be most productive in that occupational domain. Graduates of each type of higher education in economics will therefore have the highest earnings in their own occupational domain (the earnings own domain hypothesis).

Graduates of university education have acquired greater learning abilities than graduates of higher vocational education, because the qualifications they acquired are of a higher and more academic level. These qualifications are less occupationally specific, but their learning ability will give them the ability to learn rapidly and to be adaptable to a variety of working circumstances. Thus:

4. Because of their greater learning ability, graduates of university education will relatively have less disadvantages with regard to their earnings outside their own occupational domain than graduates of higher vocational education have (the earnings alternative domain hypothesis).

\section{The data}

\subsection{The HBO monitor and the RL scanner}

Two data sets will be used for the empirical analysis of the labour market position of graduates of higher vocational education and university education in economics and business administration. The first is the so-called 'HBO Monitor', an annual survey of the labour market position and careers of graduates from higher vocational education in the Netherlands (Van de Loo, et al., 1993a, 1993b). The second is the so-called 'Arbeidsmarktscanner Rijksuniversiteit Limburg' (RL-scanner), an annual survey of the labour market position of University of Limburg graduates (Ramaekers \& Heijke, 1993). The two surveys are carried out by the Research Centre for Education and the Labour Market (ROA) of the University of Limburg in the Netherlands. 
The labour market position of graduates is measured one and a half years after they have graduated. The analysis will be restricted to students who have finished school during the year 1990/1991 in the province of Limburg. The latter restriction is made because information is available at the university level only for graduates of the University of Limburg.

Table 3.1 gives an overview of the main characteristics of the survey respondents. The table shows that there are differences between the graduates of higher vocational education and university education in economics. Higher vocational education has a higher percentage of female graduates, and its graduates are a little younger than the graduates of university education in economics. The reason for this is obvious, because the study schedule for HVE students is more strictly confined to four years than the programme for university students. Moreover, the initial education for some of the HVE graduates is senior general secondary education, for which the official study duration is five years, whereas the university preparatory education course lasts six years. University graduates have more managerial experience, and fewer of them work in the profit sector. Although fewer university graduates have found work at the level of their qualifications, their average earnings are higher than the average earnings of the graduates of higher vocational education. More university graduates enter their first job without a period of unemployment, and they are less often unemployed than the graduates of higher vocational education.

Table 3.1

Main characteristics of the respondents

\begin{tabular}{|c|c|c|c|c|}
\hline \multirow[t]{2}{*}{ Variables } & \multicolumn{2}{|c|}{$\begin{array}{l}\text { Higher vocational } \\
\text { education } \\
(N=140)\end{array}$} & \multicolumn{2}{|c|}{$\begin{array}{l}\text { University } \\
\text { education } \\
(\mathrm{N}=76)\end{array}$} \\
\hline & $\%$ & $(\mathrm{~N})$ & $\%$ & $(\mathrm{~N})$ \\
\hline Females & 40.3 & (56) & 25.0 & (19) \\
\hline Average age (years) & 23.3 & (139) & 24.7 & (76) \\
\hline Preliminary educ.is higher vocational education in economics & - & & 17.1 & (13) \\
\hline Managerial experience & 19.0 & (26) & 43.4 & (33) \\
\hline Working in an organisation with $\geq 50$ employees & 68.5 & (63) & 68.7 & (46) \\
\hline Working in the profit sector & 91.2 & (83) & 67.6 & (46) \\
\hline Average earnings ${ }^{a}$ (Dutch guilders per month) & 3,195 & & 4,049 & \\
\hline Match between level acquired and level required skills & 80.7 & (71) & 69.7 & (46) \\
\hline Entered first job without unemployment & 57.9 & (66) & 65.8 & (48) \\
\hline Employed $^{\mathrm{b}}$ & 89.4 & (93) & 84.2 & (64) \\
\hline Unemployed $^{c}$ & 7.1 & (10) & 4.3 & (3) \\
\hline
\end{tabular}

a Gross monthly income for a forty-hour week

${ }^{b}$ Respondents are recorded as employed if they have a job for at least 12 hours a week (CBS, 1993)

c Respondents are recorded as unemployed if they don't have a job for at least 12 hours a week, they are actively searching for a job (signing on at the Employment Exchange), and they are available to start work within 2 weeks (CBS, 1993) 


\subsection{The statistical definition of 'occupational domain'}

The matching models in section 2.2 have been used to show that some types of education have a comparative advantage over other types of education in certain occupations. Comparative advantage is treated as a feature of a type of education. The assumption that types of education can have comparative advantages over other types of education implies that every type of education has its own occupational domain. In other words: for every type of education a range of occupations can be defined in which this type of education has a comparative advantage over other types of education. Therefore, the occupational domains can overlap only if none of the types of education have a comparative advantage over another type of education.

The occupational domains of higher vocational education (HVE domain) and university education (UV domain) in economics and business administration have to be determined on the basis of the restricted data set described above. There are two problems with regard to the reliability of the empirical definition of the occupational domains. In the first place, the occupational domains could be defined only by using the respondents' own statements about the level of the skills which they had acquired and their perception of what level of skills was required by their employer for the jobs they work in. We do not have an objective measure to determine the occupational domains. In the second place, the small number of respondents means that, occupational groups, rather than individual occupations, had to be assigned to the HVE and UV occupational domains. We have used the following rules to determine the occupational domains.

1) If at least $50 \%$ of the graduates of type $A$ education working in occupation 1 state that the level of their qualifications matches the job requirements, then occupation 1 belongs to the occupational domain of type of education $A$;

2) If at least $50 \%$ of the graduates of types of education $A$ and $B$, working in occupation 1 , state that the level of their qualifications matches with the job requirements, than occupation 1 belongs to the occupational domain of the type of education which has the greatest number ${ }^{3}$ of graduates in occupation 1.

3) If less than $50 \%$ of the graduates of both types of education, working in occupation 1 , state that the level of their qualifications matches with the job requirements, than occupation 1 belongs to the domain of residual occupations and will be excluded from the analysis.

The resulting occupational domains are shown in appendix 1 . In all, $28 \%$ of the UV graduates in economics had found a job outside their own occupational domain, most of them $(25 \%$ of the total) in the HVE domain. Slightly fewer $(25 \%)$ of the HVE graduates in economics had found a job outside their own occupational domain, and just $18 \%$ of the

3. This number is obtained after weighting by the total number of respondents in the survey from each type of education. 
total were working in the UV domain. The few graduates who found work in occupations which are not part of either the UV or HVE domain are left out of the analysis.

\section{Empirical analysis}

\subsection{Job opportunities}

The previous sections have shown that graduates' educational attainment affects their job opportunities both within and outside their occupational domain. To investigate these effects, an explanatory model will be formulated in which it is assumed that graduates from university and higher vocational education in economics and business administration have job opportunities in the UV and HVE domains, as defined in the previous section. The model will be used to establish what determinants affect the probability of economics graduates having a job in one or other of two domains. In addition to educational attainments, other factors such as age, sex, managerial experience and preliminary education may also have an influence on graduates' job opportunities. Because this paper focuses on the relative positions of higher vocational and university education graduates on the labour market, these other factors will be used as control variables.

Because the dependent variable - the probability of having a job in the HVE domain is a dummy variable, the logit method has been chosen to estimate the model. ${ }^{4}$ In terms of logit, the model can be written as:

$$
P(\text { domain HVE })=\frac{1}{1+\exp -\left(\alpha_{0}+\alpha_{1} U V+\alpha_{2} A G E+\alpha_{3} F E M+\alpha_{4} M E X P+\alpha_{5} P R E D\right)}
$$

in which UV is the acquired type of education. This variable has a value of 1 if the subject had a university education, and zero if the subject had a higher vocational education. The variable AGE is the age of the graduates at the moment they finished study. The variables FEM, MEXP and PRED are dummy variables. FEM has a value of 1 for female graduates, MEXP has a value of 1 for graduates with managerial experience, and PRED - the previous education - is 1 for university graduates who also have a previous completed qualification in economics in higher vocational education. Otherwise PRED is zero.

In accordance with the hypotheses deduced in section 2.4 , the sign of UV is expected to be negative, because it is supposed that graduates of university education will have fewer job opportunities in the HVE domain than graduates of higher vocational education. Furthermore, the sign of PRED will be positive, because university graduates who have attained a qualification in higher vocational education previously would be expected to

4. For more details, see Demaris (1992) and Amemiya (1981). 
have more opportunities in the HVE domain than graduates who have university education only.

The results of a logistic regression analysis, shown in table 4.1, prove that managerial experience and the type of education have a significant effect on the probability of working in the HVE domain. A background in university education in economics, rather than higher vocational education in the same field, has the expected negative correlation with the probability of working in the HVE domain, and so has the attainment of managerial experience. The effect of a previous HVE qualification in economics on the probability of working in the HVE domain is almost significant, and has the expected positive sign. From these results it may be concluded that graduates of higher vocational education have a greater probability of working in the HVE domain than university graduates, especially in comparison with university graduates who have not completed higher vocational education previously, although it should be noted that last restriction is not significant.

Not only the sign of the effect of having university education, but also the size of this effect is investigated. This can be determined with the help of equation 4.1. Filling in the estimated logistic regression coefficients and the mean values of the variables in this equation for graduates from higher vocational education gives the estimated probability of having $a$ job in the HVE domain for the average graduate from higher vocational education: $82 \%$. The probability that university graduates who differ from the average graduate of higher vocational education only in their educational attainment will have a job in the HVE domain is $22 \%$. Thus the probability that graduates of higher vocational education will work in the HVE domain is 60 percentage points higher than the probability for university graduates with the same characteristics.

Table 4.1

Results of a logistic regression of the probability of working in the occupational domain of higher vocational education $(\mathrm{N}=145)$

\begin{tabular}{lcc}
\hline Variable & Regression coefficient & t-value \\
\hline University education in economics (UV) & $-2.79^{* * *}$ & -5.54 \\
Age (AGE) & -0.06 & -0.44 \\
Female (FEM) & -0.76 & -1.59 \\
Managerial experience (MEXP) & $-0.91^{*}$ & -1.99 \\
Previous HVE education (PRED) & 1.40 & 1.86 \\
Intercept & 3.40 & 1.02 \\
-2 log likelihood $=145.260 \quad$ df $=5$ significance $=0.00$ & \\
& & \\
$* * \quad=$ significant at $1 \%$ level &
\end{tabular}


Since those working in the residual occupations have been excluded, the probabilities of working in the UV domain are the complements of the probabilities for the HVE domain, and can easily be derived by subtracting the figures above from 1 . However, in order to get an impression of the significance of the characteristics of the graduates for these results, the probability of having a job in the UV domain will be calculated by replacing the average characteristics of HVE graduates with the average characteristics of UV graduates, in the estimated probability function. The result of these calculations show that university graduates have a $78 \%$ probability of working in the UV domain. The probability that graduates from higher vocational education will be working in the UV domain is $17 \%$. So the probability that graduates of university education will work in the UV domain is 61 percentage points higher than the probability for graduates of higher vocational education with the same characteristics. It is clear that the differences between the average characteristics of UV and HVE graduates have only a negligible effect on the calculated job opportunities.

It can be concluded that graduates of the two types of education are most likely to find a job in their own occupational domain. This result is in accordance with the own domain hypothesis. Furthermore, the proportion of university graduates working in the HVE domain is higher than the proportion of graduates of higher vocational education working in the UV domain. Of the university graduates whose characteristics correspond to the average characteristics of HVE graduates, $22 \%$ work in the HVE domain, while only $17 \%$ of the graduates of higher vocational education whose characteristics correspond to the average UV graduate work in the UV domain. This conclusion is in accordance with the alternative domain hypothesis. University graduates have more job opportunities in the alternative occupational domain than graduates of higher vocational education. But it should be noted that the alternative domain of the HVE graduates was restricted to the UV domain, so that their opportunity to work at a lower level, in the domain of intermediate vocational education, has not been considered, whereas the opportunity to work at a lower level has been taken into account for university graduates.

\subsection{Earnings}

It is assumed that the type of educational qualification which graduates have learned influences their earnings. Other possible determinants include the occupational domain in which they work, age, and other relevant qualifications besides the formal educational qualification. To investigate these influences on graduates' earnings, an explanatory model was formulated and estimated separately for the HVE and UV domains. The model is estimated with the help of multiple regression analysis and can be written as follows:

In WAGE $=\beta_{0}+\beta_{1} U V+\beta_{2} A G E+\beta_{3} F E M+\beta_{4} M E X P+\beta_{5} P R E D+\beta_{6} S I Z E+\beta_{7} P R O F I T$ 
in which earnings are measured as the natural logarithm of the gross monthly income, so that the difference between incomes of 1,000 and 2,000 is registered as greater than the difference between incomes of 5,000 and 6,000 . The variables have the same meaning in the wage model as in the job probability equation (4.1), but two new dummy variables have been added. The variable SIZE has a value of 1 if a graduate is working in an organisation with fifty or more employees. The variable PROFIT has a value of 1 if the graduate is working in the profit sector.

In accordance with the hypotheses which assume that university education imparts a higher level of skills than higher vocational education (hypothesis 2, implicitly, and hypotheses 4 explicitly), the sign of UV is expected to be positive in both domains, so that UV graduates who have the same characteristics as the HVE graduates, except that they studied at university, will earn more than HVE graduates. If graduates of each type have a comparative advantage in their own domain (the matching model), they would also be expected to earn most when working in their own domains. The sign of PRED is expected to be positive in the HVE domain and not significant in the UV domain, because university graduates with a previous HVE education may benefit from the additional occupational skills in the HVE domain, whereas these skills will offer no extra value in the UV domain. The signs of AGE and MEXP are expected to be positive, since these variables represent additional experience which may have productive effects. The sign of FEM may be negative because of wage discrimination against women.

The results of the regression analysis for the HVE domain are shown in table 4.2. They indicate that, in the HVE domain, the type of education, the size of the organisation in which graduates are working, and gender all have a significant impact on earnings. In this occupational domain, graduates from university education have significantly more earnings than graduates of higher vocational education, and females earn significantly less than males. In organisations with fifty or more employees, earnings are significantly higher than in smaller organisations.

To investigate the impact of the type of education on earnings in the HVE domain more precisely, the earnings of HVE and UV graduates working in the HVE domain whose characteristics correspond to the average profile of graduates from higher vocational education are calculated, by entering the mean values of the characteristics of HVE graduates into the earnings equation that was estimated for the HVE domain (see for the results: table 4.3). The calculation yields a gross monthly income of 3180 Dutch guilders for HVE graduates, and 3655 Dutch guilders for university graduates. Thus, in the HVE domain, graduates from higher vocational education earn about 501 Dutch guilders less than university graduates, who differ from them only in having completed the university education.

Table 4.2 presents the estimation results of the earnings equation for the UV domain too. 
The table shows that university graduates earn significantly more in the UV domain than graduates of higher vocational education. Furthermore, graduates who are working in the profit sector have significantly more earnings than other graduates. The other factors do not have significant effects in this domain.

Table 4.2

Results of a multiple regression analysis to explain In earnings in the HVE and UV domain

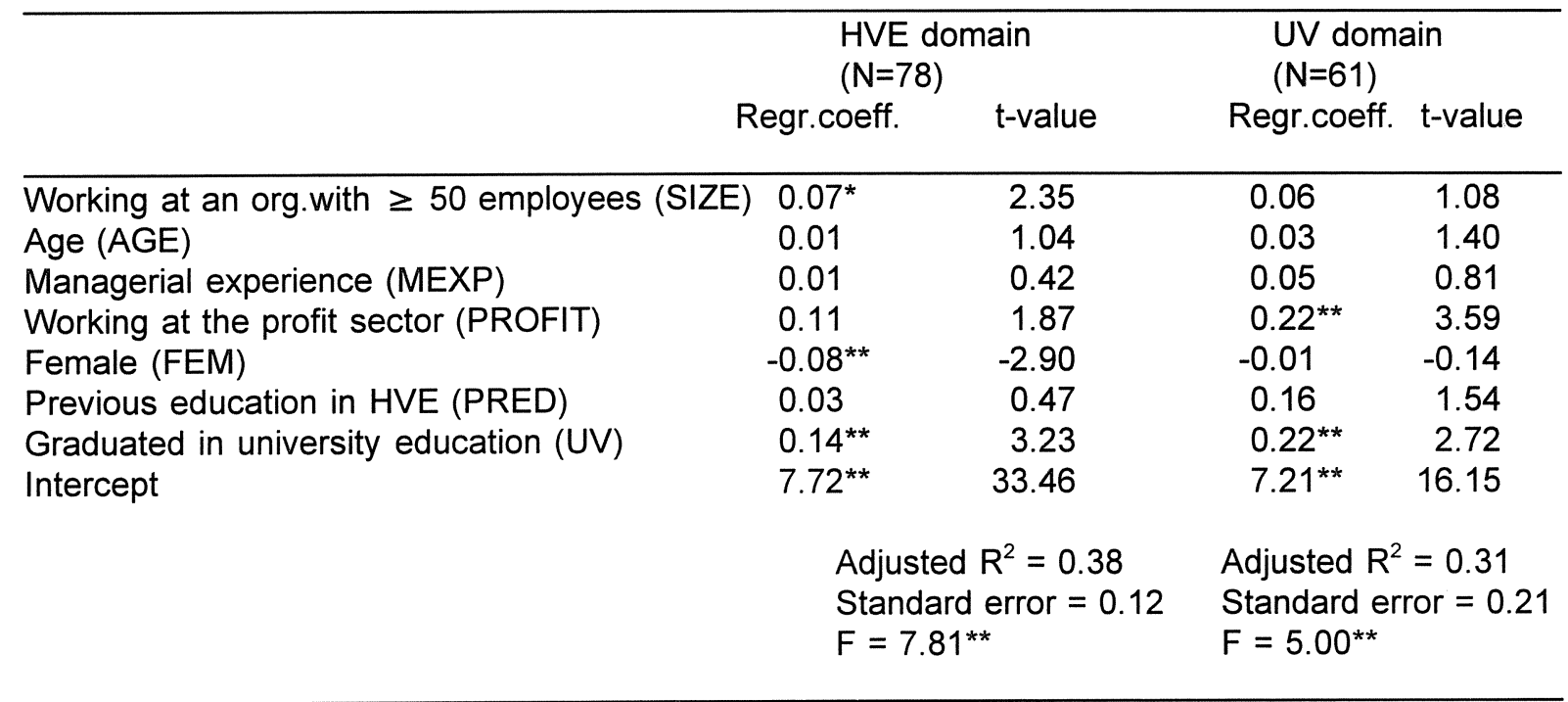

** $\quad=$ significant at $1 \%$ level

* $\quad=$ significant at $5 \%$ level

To investigate the impact of educational type on earnings in the UV domain further, the mean values of the characteristics of the university graduates are entered into the estimated earnings equations for both types of graduates working in the UV domain (see for the results table 4.3). The outcome for university graduates is 4083 Dutch guilders, and for graduates of higher vocational education, 3276 Dutch guilders. This means that, in the UV domain, university education is rewarded with 807 Dutch guilders more in earnings than higher vocational education.

Table 4.3 also shows the earnings for males and females, because in the HVE domain females have significantly lower earnings. It can be seen that the graduates of the two types of education earn most when working in their own occupational domain, except that females who graduated in higher vocational education earn more if they find a job in the UV domain. So these results are not fully in accordance with the earnings own domain hypothesis. University graduates - both women and men, and working in either domain - earn significantly more than graduates of higher vocational education. These results support the earnings alternative domain hypothesis. However, women earn less than men in both occupational domains, especially in the HVE domain where the effect is significant. Apparently, employers perceive female graduates in the HVE domain as relatively less productive than men, since they earn significant less in that domain than male graduates who are otherwise similar. Why this appears only in the HVE domain, is not clear. 
Table 4.3

Summary of the gross monthly earnings in the occupational domains (Dutch guilders):

\begin{tabular}{llll}
\hline & HVE domain & & \\
& Males & Females & Total \\
\hline HVE graduate with HVE characteristics & 3,315 & 3,050 & 3,180 \\
UV graduate with HVE characteristics & 3,810 & 3,506 & 3,655 \\
UV graduate with UV characteristics & 3,802 & 3,498 & 3,723 \\
& UV domain & & \\
& & & \\
& Males & Females & Total \\
\hline UV graduate with UV characteristics & 4,093 & 4,052 & 4,083 \\
HVE graduate with UV characteristics & 3,285 & 3,252 & 3,276 \\
HVE graduate with HVE characteristics & 3,195 & 3,163 & 3,179 \\
\hline
\end{tabular}

\section{Conclusions}

This paper focuses on the competition on the labour market between higher vocational education and university education in economics and business administration. Important differences between these types of education are in their educational objectives and the level of the qualifications which can be acquired. Higher vocational education is intended to focus on occupational training, whereas university education ought not to be connected with specific occupations but rather with an academic discipline. Both types of education provide high level qualifications. The qualifications acquired in university education are more transferable to a broad range of occupations than higher vocational education qualifications, because graduates of university education have better opportunities to develop their learning abilities, and their qualifications are less strongly connected with specific occupations. To clarify these differences, three dimensions were distinguished: the qualification level, the acquired learning ability or the occupational specificity of the qualifications, and the relative quality of the match between the level of the qualifications required and acquired. The impact of these differences on the labour market are explored with the help of the human capital theory, the job competition model and a job matching model.

The results of the empirical analyses show that the type of education has a significant impact on the opportunities of graduates to find a job in one of the two occupational domains. Graduates of both types of higher education in economics are most likely to find a job in their own occupational domain. The results indicate also that graduates of both types of education earn most when they work in their own domain, except for female graduates of higher vocational education who earn most when they work in the UV 
domain. Finally, graduates of university education earn significantly more than graduates of higher vocational education, regardless of the occupational domain in which they work.

The human capital theory assumes that the level of the educational attainment determines the earnings of the graduates. The fact that university graduates in economics earn more than economists from higher vocational education, regardless of which occupational domain they are working in, supports this thesis. Our results suggest that university education in economics is at a higher level than the higher vocational education course in economics, and thus produces more productive workers who are better paid. However, the fact that wages for graduates from the same type of education differ in the two occupational domains, is not in accordance with the human capital theory. Graduates of university education earn, for example in the HVE domain lower wages than in the UV domain. But their wages in the HVE domain are still better than the wages of the HVE graduates who are working in the HVE domain.

The job competition model assumes that the earnings of the graduates depend on the kind of occupation they are working in. The fact that the wages differ in the two occupational domains is evidence in favour of the job competition model. But the fact that the wages of the graduates of both types of education are different in the same occupational domain is not in accordance with the theory. For instance, in the HVE domain, university graduates in economics earn much more than graduates from higher vocational education.

In the job matching theory, the earnings of the graduates are dependent of the combination of personal abilities and job characteristics. In general, the results of the empirical analysis correspond the most closely with the job matching theory. Graduates from both university and higher vocational education are most likely to work in their own occupational domain, where their productive advantages can be exploited to the best advantage and where they, except for female graduates of higher vocational education, consequently have more earnings than outside that domain. Furthermore, as noted above, university graduates in economics appear to have greater productive capacities, in general, than economics graduates from higher vocational education, since they also earn more in the HVE domain than the HVE graduates. This finding confirms the job matching theory, since it is in accordance with the concept of comparative advantage.

\section{References}

Amemiya, T, (1981) Qualitative response models: a survey, in: Journal of Economic Literature, vol 19, December 1981, pp.1483-1536.

Becker, G.S. (1962) Investment in human capital: a theoretical analysis, in: Journal of Political Economy, vol 70, no.1, pp. 9-49. 
Bloom, B.S. et al.(1956) Taxonomy of the Educational Objectives, Handbook 1: Cognitive Domain, David McKay Inc, New York.

CBS (1980) Arbeidskrachtentelling 1977, 's-Gravenhage.

CBS (1993) Werken en leren in Nederland 1993, Voorburg/Heerlen.

CBS (1994a) Enquête Beroepsbevolking 1993, Voorburg/Heerlen.

CBS (1994b) Werken en leren in Nederland 1994, Voorburg/Heerlen.

Demaris, A. (1992) Logit modelling. Practical applications, Sage University paper 86, London.

Frederix, L.L.M. (1988) Visies op HBO en beroepspraktijk. Een exploratief onderzoek naar visies van experts op de toekomstige relatie van $\mathrm{HBO}$ en beroepspraktijk, PhD thesis, University of Limburg, Maastricht.

Hartog, J. (1992) Capabilities, allocation and earnings, Kluwer Academic Publishers, Dordrecht.

Hartog, J \& Visser, M. (1987) De juiste man op de juiste plaats, doet het ertoe? OSA working document W33, Den Haag.

Huijgen, F. (1989) De kwalitatieve structuur van de werkgelegenheid in Nederland, deel 3, Bevolking in loondienst en functiestructuur in 1977 en 1985, OSA preparatory study no. V33, 'sGravenhage.

Jovanovic, B. (1979) Job Matching and the Theory of Turnover, in: Journal of Political Economy, Vol 87, pp. 972-990.

Koss-Fiszer, A.J. (1988) Het economisch rendement van onderwijs, in: Supplement bij de Sociaaleconomisch Maandstatistiek, Centraal Bureau voor de Statistiek, Voorburg/Heerlen, no. 6, pp. 411.

Loozen, S.W.H.C. \& R.J.P. Dekker (1993) De relatie tussen beroep en opleiding. Uitkomsten van de Arbeidskrachtentelling en de Enquête beroepsbevolking, in: Supplement bij de Sociaaleconomische Maandstatistiek, Centraal Bureau voor de Statistiek, Voorburg/Heerlen, no. 4, pp. 410.

Ministerie van Onderwijs en Wetenschappen (1985) De toekomst van het hoger onderwijs en wetenschappelijk onderzoek in Nederland, Directie Toekomstverkenningen, 's-Gravenhage.

Ministerie van Onderwijs en Wetenschappen (1994) Ramingen, leerlingen en studenten 1994, Deel 2: Methodiek en tabellen, 's-Gravenhage.

OECD (1993) Education at a glance, Paris.

OSA (1994) Rendement van opleiding en allocatie van arbeid, OSA-rapport nr. 19, 's-Gravenhage.

Ramaekers, G.W.M. \& J.A.M. Heijke (1994) Discrepancies in the labour market of RL-educated economists, in: W.H. Gijselaars et al. (eds.) Educational Innovation in Economics and Business Aministration. The Case of Problem-based Learning, Kluwer Academic Publishers, Dordrecht/Boston, pp 370-381.

ROA (1989) De arbeidsmarktperspectieven van beroepsklassen en opleidingstypen in 1992. Rapportage I-SEE!, Researchcentrum voor Onderwijs en Arbeidsmarkt, ROA-R-1989/7, Maastricht.

ROA (1993) Statistical Appendix. The Labour Market by Education and Occupation to 1998, Research Centre for Education and the Labour Market, ROA-R-1993/10BE, Maastricht.

Ramaekers, G.W.M. \& J.A.M. Heijke (1993), Arbeidsmarktscanner Rijksuniversiteit Limburg: basismeting cohort '91, ROA-R-1993/13, ROA, Maastricht.

Samuelson, P.A. \& W.D. Nordhaus (1985) Economics, New York, McGraw-Hill, Inc., pp. 834-835.

Schultz, T.W. (1961) Investment in human capital, in: The American Economic Review, vol 11, pp. 
$1-17$.

SCP (1994) Sociaal en Cultureel Rapport 1994, Rijswijk.

Thurow, L.C. (1975) Generating Inequality. Mechanisms of Distribution in the U.S. Economy, Basic Books Inc. Publishers, New York.

Thurow, L.C. (1979) A Job Competition Model, in: M.J. Piore (eds) Unemployment and Inflation: institutionalist and structuralist views, White Plains, NY: Sharpe, pp. 17-32.

Van de Loo, P.J.E. et al. (1993a) De arbeidsmarktpositie van afgestudeerden van het hoger beroepsonderwijs, HBO-Monitor 1992, HBO-Raad, Den Haag.

Van de Loo, P.J.E. et al. (1993b) De arbeidsmarktpositie van afgestudeerden van het hoger beroepsonderwijs, HBO-Monitor 1992, Statistisch supplement, HBO-Raad, Den Haag. 


\section{Appendix 1 The classification of occupational groups}

The occupational domain of higher vocational education (HVE domain):

\begin{tabular}{lrrrr}
\hline Occupational groups & Higher vocational education \\
& $\mathrm{N}^{\mathrm{a}}$ & $\begin{array}{r}(\%)^{\mathrm{b}} \\
\text { Technologists and related workers }\end{array}$ & $\begin{array}{r}\text { University } \\
\mathrm{N}^{\mathrm{c}}\end{array}$ & $\begin{array}{r}\text { education } \\
(\%)^{\mathrm{d}}\end{array}$ \\
Information and systems analysts & 1 & $(100)$ & - & $(-)$ \\
Programmers and sustem managers & 7 & $(86)$ & - & $(-)$ \\
Personnel officers & 7 & $(86)$ & - & $(-)$ \\
Clerical Supervisors & 4 & $(100)$ & 1 & $(0)$ \\
Secretaries and typists & 1 & $(100)$ & - & $(-)$ \\
Bookkeepers and cashiers & 2 & $(50)$ & - & $(-)$ \\
Insur., real estate, sec. and business services salesman & 43 & $(88)$ & 15 & $(40)$ \\
Total & 66 & $(100)$ & - & $(-)$ \\
& & & 16 & \\
\hline
\end{tabular}

The occupational domain of university education (UV domain):

Occupational groups Higher vocational education University education

\begin{tabular}{lrrrr}
\hline & $\mathrm{N}$ & $(\%)$ & $\mathrm{N}$ & $(\%)$ \\
\hline Business managers and job analysts & - & $(-)$ & 2 & $(50)$ \\
Economists and marketing experts & 2 & $(100)$ & 18 & $(95)$ \\
Accountants and tax consultants & 2 & $(100)$ & 8 & $(50)$ \\
Teachers (intermediate and higher education) & - & $(-)$ & 5 & $(100)$ \\
Community workers & - & $(-)$ & 1 & $(100)$ \\
Managers & 3 & $(100)$ & 3 & $(67)$ \\
Civil servants: educational field & - & $(-)$ & 1 & $(100)$ \\
Civil servants: technical field & - & $(-)$ & 2 & $(100)$ \\
Civil servants: economic field & 2 & $(100)$ & 2 & $(50)$ \\
Bank employees and related workers & 7 & $(43)$ & 5 & $(80)$ \\
Material- and production planners & - & $(-)$ & 1 & $(100)$ \\
Managers wholesale and retail trade & - & $(-)$ & 1 & $(100)$ \\
Total & 16 & & 49 &
\end{tabular}


Residual occupational groups

\begin{tabular}{lll}
\hline Occupational groups $\quad$ Higher vocational education & University education
\end{tabular}

\begin{tabular}{lrrrr}
\hline & N & $(\%)$ & N & $(\%)$ \\
\hline Mail distribution clerks & - & $(-)$ & 2 & $(0)$ \\
Correspondents and other administrative workers & 3 & $(33)$ & - & $(-)$ \\
Sales supervisors and buyers & 1 & $(0)$ & - & $(-)$ \\
Salesmen, shop assistants and related workers & 1 & $(0)$ & - & $(-)$ \\
Housekeeping and related service supervisors & 1 & $(0)$ & - & $(-)$ \\
Total & 6 & & 2 & \\
\hline
\end{tabular}

a Total number of graduates working in each occupational group.

$\mathrm{b}$ The percentage of the total number of graduates working in that occupational group who say that the level of the skills acquired matches the level of the required skills.

c Total number of graduates working in each occupational group.

$d$ The percentage of the total number of graduates working in that occupational group who say that the level of the skills acquired matches the level of the required skills. 


\section{Appendix 2 The mean characteristics of the respondents employed}

\begin{tabular}{|c|c|c|c|c|}
\hline \multirow[t]{2}{*}{ Variables } & \multicolumn{2}{|c|}{$\begin{array}{l}\text { Higher vocational } \\
\text { education } \\
(\mathrm{N}=140)\end{array}$} & \multicolumn{2}{|c|}{$\begin{array}{l}\text { University } \\
\text { education } \\
(\mathrm{N}=76)\end{array}$} \\
\hline & & & $\%$ & (N) \\
\hline Females & 50.0 & (46) & 25.0 & (16) \\
\hline Average age (years) & 23.4 & (93) & 24.8 & (64) \\
\hline Preliminary educ.is higher vocational education in economics & - & & 20.3 & (13) \\
\hline Managerial experience & 19.6 & (18) & 42.2 & (27) \\
\hline Working in an organisation with $\geq 50$ employees & 68.5 & (63) & 71.4 & (45) \\
\hline Working in the profit sector & 91.2 & (83) & 67.2 & (43) \\
\hline Average earnings $^{\mathrm{a}}$ (Dutch guilders per month) & 3,195 & & 4,027 & \\
\hline Match between level acquired and level required skills & 80.7 & (71) & 69.4 & (43) \\
\hline Entered first job without unemployment & 63.4 & (59) & 67.2 & (43) \\
\hline
\end{tabular}

a Gross monthly income for a forty-hour week 